\title{
GEOLOGIC FRAMEWORK AND HYDROGEOLOGIC CHARACTERISTICS OF THE EDWARDS AQUIFER RECHARGE ZONE, BEXAR COUNTY, TEXAS
}

\section{U.S. GEOLOGICAL SURVEY}

Water-Resources Investigations Report 95-4030

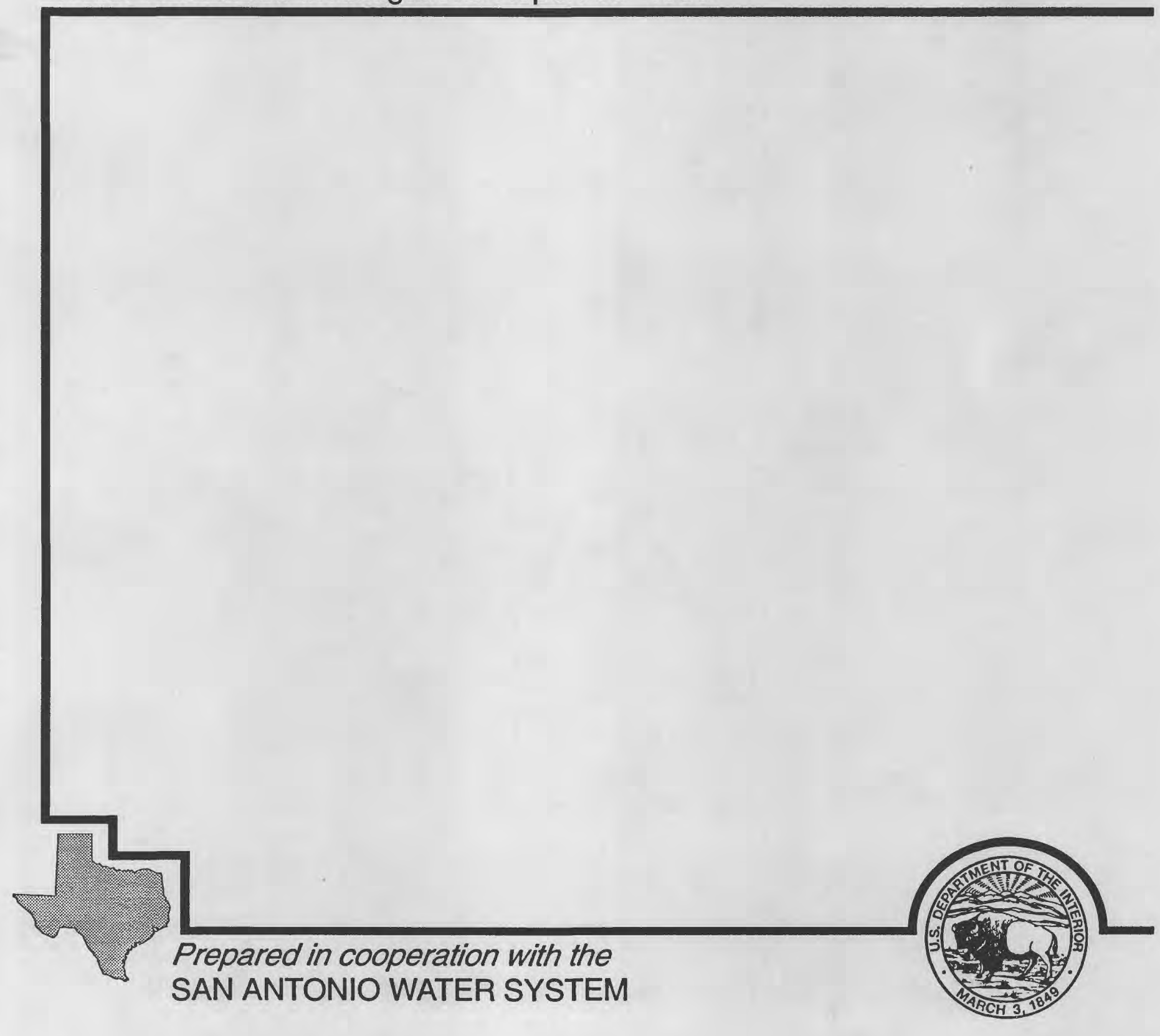




\section{GEOLOGIC FRAMEWORK AND HYDROGEOLOGIC CHARACTERISTICS OF THE EDWARDS AQUIFER RECHARGE ZONE, BEXAR COUNTY, TEXAS}

By William G. Stein and George B. Ozuna

U.S. GEOLOGICAL SURVEY

Water-Resources Investigations 95-4030

Prepared in cooperation with the SAN ANTONIO WATER SYSTEM 


\title{
U.S. DEPARTMENT OF THE INTERIOR BRUCE BABBITT, Secretary
}

\author{
U.S. GEOLOGICAL SURVEY
}

Gordon P. Eaton, Director

Any use of trade, product, or firm names is for descriptive purposes only and does not imply endorsement by the U.S. Government.

For additional information write to:

District Chief

U.S. Geological Survey 8011 Cameron Rd.

Austin, TX 78754-3898
Copies of this report can be purchased from:

U.S. Geological Survey

Earth Science Information Center

Open-File Reports Section

Box 25286, Mail Stop 517

Denver Federal Center

Denver, CO 8.0225-0046 


\section{CONTENTS}

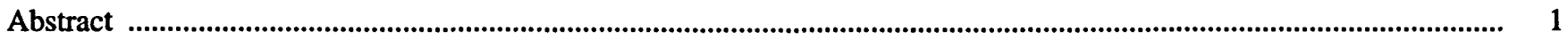

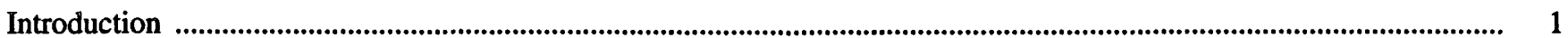

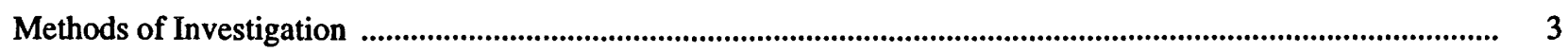

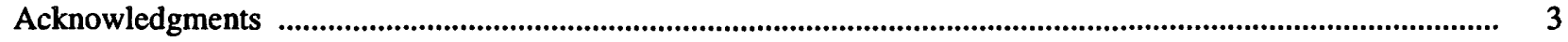

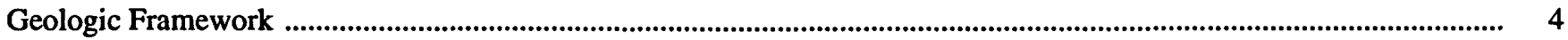

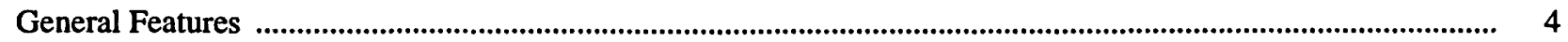

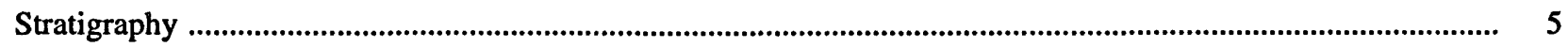

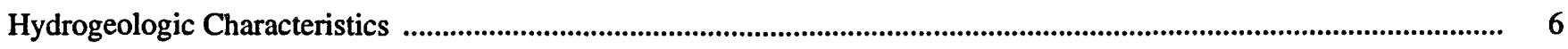

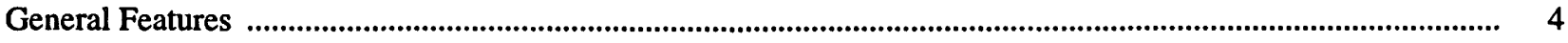

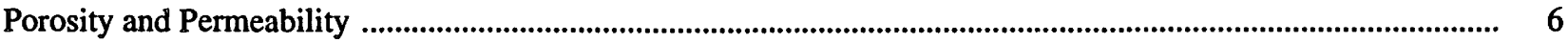

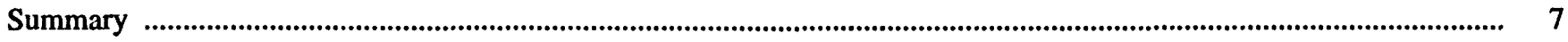

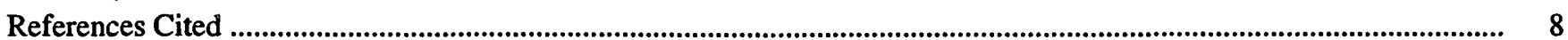

\section{PLATE}

[Plate is in pocket]

1. Map showing hydrogeologic subdivisions of the Edwards aquifer recharge zone, Bexar County, Texas.

\section{FIGURE}

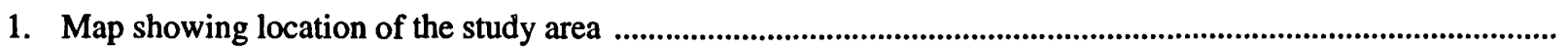

\section{TABLE}

1. Summary of the lithologic and hydrologic properties of the hydrogeologic subdivisions of the Edwards aquifer outcrop, Bexar County, Texas

\section{CONVERSION FACTORS AND VERTICAL DATUM}

\begin{tabular}{rll}
\hline Multiply & By & To obtain \\
\hline acre-foot (acre-ft) & 1,233 & cubic meter \\
acre-foot per year (acre-ft/yr) & 1,233 & cubic meter per year \\
foot (ft) & 0.3048 & meter \\
foot per mile (ft/mi) & 0.1894 & meter per kilometer \\
mile (mi) & 1.609 & kilometer
\end{tabular}

Sea level: In this report, "sea level" refers to the National Geodetic Vertical Datum of 1929—a geodetic datum derived from a general adjustment of the first-order level nets of the United States and Canada, formerly called Sea Level Datum of 1929. 


\title{
Geologic Framework and Hydrogeologic Characteristics of the Edwards Aquifer Recharge Zone, Bexar County, Texas
}

\author{
By William G. Stein and George B. Ozuna
}

\begin{abstract}
In Bexar County, residential and commercial development on the Edwards aquifer recharge zone is increasing. The aquifer possibly can be contaminated by spills, leakage of hazardous materials, or runoff from the rapidly developing urban areas that surround, or are built on, the intensely faulted and fractured, karstic limestone outcrops characteristic of the recharge zone. Furthermore, some of the hydrogeologic subdivisions that compose the Edwards aquifer have greater effective porosity than others. The areas where the most porous subdivisions crop out might provide efficient avenues for contaminants to enter the aquifer.
\end{abstract}

The Edwards aquifer recharge zone has relatively large permeability resulting, in part, from the development or redistribution of secondary porosity. Lithology, stratigraphy, diagenesis, and karstification account for the effective porosity and permeability in the Edwards aquifer outcrop. Karst features that greatly enhance effective porosity in the outcrop area include sinkholes and caves.

Hydrogeologic subdivision VI, the Kirschberg evaporite member, appears to be the most porous and permeable subdivision within the Kainer Formation. Hydrogeologic subdivision III, the leached and collapsed members, undivided, is the most porous and permeable subdivision within the Person Formation. Hydrogeologic subdivision $I I$, the cyclic and marine members, undivided, is moderately permeable, with both fabric- and notfabric-selective porosity.

The faults in northern Bexar County are part of the Balcones fault zone. Although most of the faults in this area trend northeast, a smaller set of cross-faults trend northwest. Generally, the faults are en echelon and normal, with the downthrown blocks typically toward the coast.

\section{INTRODUCTION}

The Edwards aquifer, which comprises the Kainer and Person Formations of the Edwards Group (Rose, 1972) and the overlying Georgetown Formation in rocks of Lower Cretaceous age, is one of the most productive carbonate aquifers in the nation. The dissolution-modified, faulted limestone aquifer (Buszka and others, 1990) is the sole source of public-water supply for San Antonio (ninth largest city in the United States) and is the major source of water for Bexar County (fig. 1). In addition to providing public-water supply to more than 1 million people in south-central Texas, the Edwards aquifer supplies large quantities of water to agriculture, industry, and major springs. The major springs support recreational activities and businesses, provide flow to downstream users, and provide habitat for several threatened or endangered species.

Most recharge to the Edwards aquifer is from direct infiltration of precipitation and streamflow loss in the recharge zone. Recharge to the Edwards aquifer averaged 683,000 acre-ft/yr during 1934-92 (Bader and others, 1993, table 4.1). After entering the aquifer, the water generally moves from west to east through Bexar County, where it is discharged by wells and springs. Springflow has varied over a wide range during historical time. Annual well withdrawals from the aquifer have gradually increased from 101,900 acre- $\mathrm{ft}$ in 1934 to 542,400 acre-ft in 1989 (Bader and others, 1993, table 5.1). During the 10 years from 1983 to 1992, well discharge exceeded springflow by 22 percent (Bader and others, 1993, table 5.1).

In Bexar County, residential and commercial development on the Edwards aquifer recharge zone is 

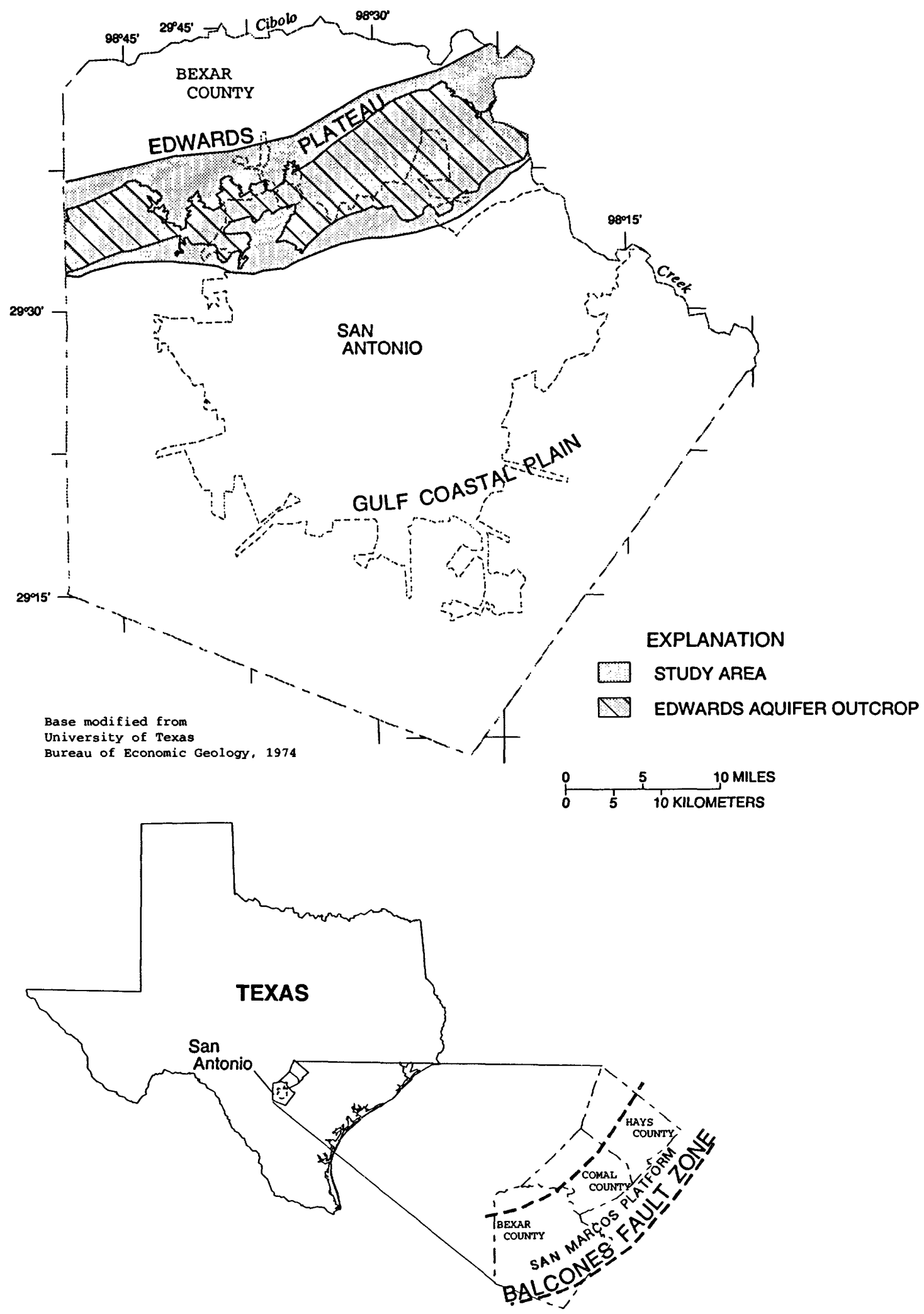

Figure 1. Location of the study area. 
increasing. According to Kipp and others (1993), a substantial increase in development activities over the Edwards recharge zone has been observed over the past year, particularly in Bexar County. Kipp and others (1993) further state that a greater threat to contamination of the Edwards aquifer comes with increased development.The aquifer possibly can be contaminated by spills, leakage of hazardous materials, or runoff from the rapidly developing urban areas that surround, or are built on, the intensely faulted and fractured, karstic limestone outcrops characteristic of the recharge zone. Furthermore, some of the hydrogeologic subdivisions that compose the Edwards aquifer have greater effective porosity than others, and in areas where they crop out, might provide efficient avenues for contaminants to enter the aquifer. According to Buszka (1987, p. 2), "carbonate aquifers, such as the Edwards, are readily susceptible to ground-water contamination where the presence of pollutants coincides with the outcrop of the aquifer." In Bexar County, the Edwards aquifer probably is most vulnerable to surface contamination in the rapidly urbanizing areas on the Edwards aquifer outcrop.

The U.S. Geological Survey, in cooperation with the San Antonio Water System, mapped the Edwards aquifer outcrop and described its hydrogeologic characteristics (porosity and permeability) to document conditions pertinent to movement and contamination of ground water.

This report describes the geologic framework and the hydrogeologic characteristics of the Edwards aquifer recharge zone in Bexar County and delineates the surface extent of the hydrogeologic subdivisions described for the confined zone of the Edwards aquifer by Maclay and Small (1976). This information will help to provide a better understanding of the processes controlling the spatial distribution of recharge and the flow of water into the aquifer. The information also will help determine the areas of the recharge zone that are most susceptible to potential contamination from landuse practices.

\section{Methods of Investigation}

The Kainer and Person Formations of the Edwards Group were divided into seven informal members by Rose (1972). Rose's (1972) categorization was further modified by Maclay and Small (1976), who added an eighth hydrogeologic subdivision, the overlying Georgetown Formation.
The outcrop of the Edwards aquifer recharge zone was mapped using the hydrogeologic subdivisions (table 1) modified from Maclay and Small (1976). The stratigraphic nomenclature and descriptions of Rose (1972) were used in mapping the geologic units for the San Marcos platform (fig. 1). The hydrogeologic subdivisions of the Edwards aquifer recharge zone in Bexar County are shown on plate 1.

Well logs and geologic map data were compiled and used in mapping the hydrogeologic subdivisions of the Edwards aquifer in the study area. The lower confining unit of the Edwards aquifer, the upper member of the Glen Rose Limestone of Lower Cretaceous age (table 1), was mapped where it is adjacent to the recharge zone. The Del Rio Clay, Buda Limestone, and Eagle Ford Group, constituting the upper confining units, were mapped along the southern boundary of the recharge zone.

Caves and other karst features were located during mapping using information from Veni (1988). Aerial photographs were used to locate the most recent rock exposures so that relatively fresh outcrops could be examined. Original land-surface topography of excavated quarries was interpolated from exposed outcrops and 7-1/2-minute quadrangles. Edwards aquifer outcrop mapping also was interpolated through areas that are covered by alluvial deposits.

Determination of fault displacement generally is difficult in carbonate rocks. Fault traces commonly are obscure and difficult to identify in the field. Fault displacements were postulated and estimated by abrupt lithologic or stratigraphic dissimilarities and at least one of the following: fault scarps, fault breccia, long linear travertine or sparry calcite deposits, or steeply dipping strata thought to represent fault-bend folds. Fault-bend folds are bedding deformation associated with fault-block movement (Suppe, 1985, p. 343). The strike of these features was measured with a compass to determine the orientation of the faults. The lengths of many of the faults were projected by lineaments visible on land surface or in aerial photographs. Faults were inferred by the location of lineaments on photographs in areas where only slight stratigraphic dissimilarities were indicated, or where the faults extended beyond the mapped area.

\section{Acknowledgments}

Special thanks are extended to George Veni, a local consulting karst hydrologist, for his assistance in 
Table 1. Summary of the lithologic and hydrologic properties of the hydrogeologic subdivisions of the Edwards aquifer outcrop, Bexar County, Texas

[Hydrogeologic subdivisions modified from Maclay and Small (1976); groups, formations, and members modified from Rose (1972); lithology modified from Dunham (1962); and porosity type modified from Choquette and Pray (1970). CU, confining unit; AQ, aquifer]

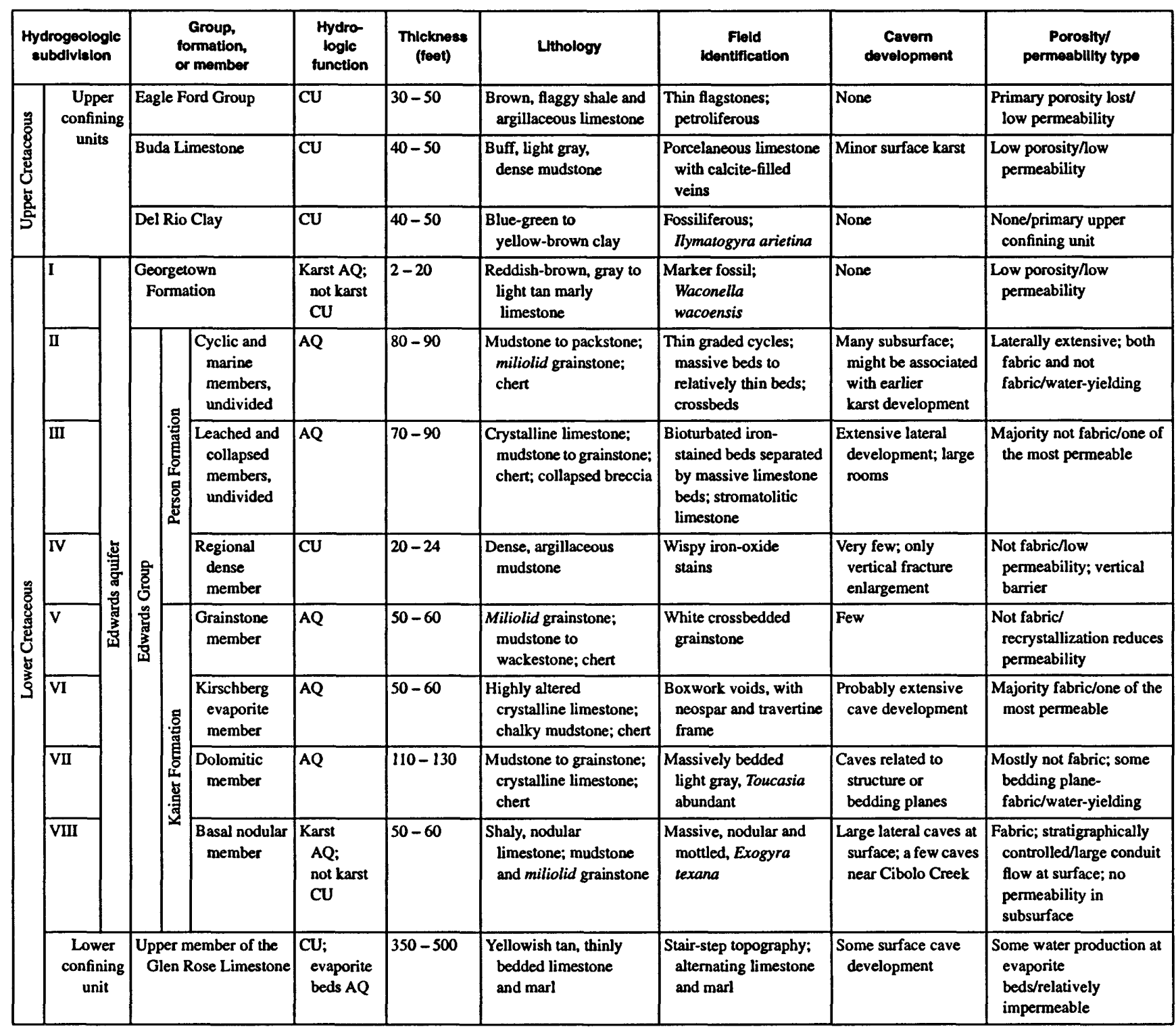

locating some of the caves while mapping in the field. The authors also express their thanks to all the property owners who granted permission to enter their property.

\section{GEOLOGIC FRAMEWORK}

\section{General Features}

A regional dip of the rocks of the hydrogeologic subdivisions of 10 to $15 \mathrm{ft} / \mathrm{mi}$ to the southeast in Bexar
County was reported by Arnow (1959, p. 19), and the thicknesses of the rocks were reported by Rose (1972). The faults in northern Bexar County are part of the Balcones fault zone (fig. 1). Although most of the faults in the area trend southwest to northeast, a smaller set of cross-faults trend southeast to northwest. Generally, the faults are en echelon and normal, with the downthrown blocks typically toward the coast (southeast). Some of the faults might not result in topographic 
relief, partly because the rocks on both sides of the fault have similar weathering characteristics, and possibly because the rate of movement is no faster than the rate of erosion.

Maclay and Small (1984, p. 33) define flowbarrier faults as faults that have vertical displacement greater than 50 percent of the total thickness of the aquifer, sufficient to juxtapose permeable layers against relatively less permeable layers. The thickness of the Edwards aquifer in Bexar County is about $450 \mathrm{ft}$; 50 percent of this is about $225 \mathrm{ft}$. Therefore, faults in the study area with a vertical displacement of about 225 $\mathrm{ft}$ or greater were designated as flow-barrier faults, as indicated by their displacements on plate 1 . A series of flow-barrier faults extends from the southwest part of the study area toward the northeast.

Some of the faults in Bexar County mark the trace of shatter zones, where the faults are not single, sharp breaks as shown by a single line placed on a map (Arnow, 1959, p. 20). Field observations of linear sparry travertine (a clear to translucent secondarily precipitated calcite) deposits within many of the fault shatter zones, and of water discharging from a fault exposed in a road cut northwest of the Loop 1604 and I-10 intersection shortly after local rainfall, support the hypothesis of ground-water flow within some faults.

\section{Stratigraphy}

In Bexar County, the Edwards aquifer consists of approximately $450 \mathrm{ft}$ of limestone, with lesser quantities of chert, dolomite, and evaporite (primarily anhydrite/gypsum) (table 1). The major formal lithostratigraphic units of the Edwards aquifer are the Kainer, Person, and Georgetown Formations (Maclay and Small, 1976). The Kainer and Person Formations are subdivided into informal members by Rose (1972). The rocks of these members, or subdivisions, were deposited in shallow to very shallow marine waters (Rose, 1972) and reflect depositional environments resulting from slight changes in water level, water chemistry, temperature, and circulation. All of these factors can cause subtle to not-so-subtle changes in the overall lithology of the various members and some changes within the individual members.

The Georgetown Formation is not known to yield water in Bexar County. Arnow (1959) noted that water-well drillers did not distinguish between the Georgetown Limestone and the underlying Edwards Limestone. Thus, according to Arnow (1959, p. 15),
"The Georgetown is part of the aquifer that comprises the Edwards and associated limestones...."

The thickness of the Kainer Formation (Rose, 1972, p. 18) ranges from about 260 to $310 \mathrm{ft}$ in Bexar County (table 1). The lithology of the Kainer Formation includes marine sediments consisting of fossiliferous (most commonly rudistids) mudstones and wackestones that grade upward into intertidal and supratidal dolomitic mudstones with evaporites, and terminate in a shallow marine miliolid grainstone. The lower part of the dolomitic member of the Kainer Formation in western Bexar County is distinctly more burrowed, similar to the facies equivalents of the burrowed member of the Fort Terrett Formation (Rose, 1972, p. 30) northwest of the study area. Major collapsed features noted elsewhere by Rose (1972) in the Kirschberg evaporite member were not evident in Bexar County. This might indicate fewer massive gypsum deposits and more interbedded limestone that would have prevented major collapses after evaporite removal.

The Person Formation (Rose, 1972, p. 19) is about $170 \mathrm{ft}$ thick in Bexar County (table 1). The regional dense member at the base of the Person Formation is a dense, argillaceous mudstone, which is easily recognized in cores and usually recognizable on geophysical logs (Small, 1985). Deposition of the Person Formation above the regional dense member continued with dolomitic biomicrite, which contains layers of collapsed breccias, burrowed mudstones, and stromatolitic limestone. The cyclic and marine members, undivided, consist of small upward-grading cycles of mudstones to grainstones that range from massive to thin beds and occasionally are crossbedded. Much of the cyclic and marine members, undivided, in Bexar County might have been removed by erosion prior to the deposition of the Georgetown Formation (Rose, 1972).

A depositional hiatus occurred before the open marine, biomicritic Georgetown Formation (Rose, 1972) was deposited. Parts of the Person Formation were above sea level during this time and were substantially eroded along the ridge of the San Marcos platform (Rose, 1972). The Georgetown Formation generally is a marly limestone and usually contains the brachiopod Waconella wacoensis, formerly Kingena wacoensis (Roemer), pectens, and other pelecypods. Most exposures of the Georgetown Formation that were identified in the study area were from 2 to $5 \mathrm{ft}$ thick, and consisted of dark reddish-brown weathered and friable material with some shaly limestone 
remnants. However, an outcrop in a quarry near Helotes Creek, east of FM 1560, contains an unweathered tannish-yellow biomicrite sequence of Georgetown Formation that is approximately $20 \mathrm{ft}$ thick. This particular Georgetown Formation outcrop evidently has undergone a different diagenetic history than the other Georgetown Formation outcrops in Bexar County.

The Upper Cretaceous Del Rio Clay, Buda Limestone, and Eagle Ford Group overlie the Georgetown Formation (pl. 1, table 1). The Del Rio Clay is a weathered, poorly compacted, friable, blue-green to yellowbrown clay, with some areas having accumulations of Ilymatogyra arietina, formerly Exogyra arietina (Roemer). The contact between the Del Rio Clay and the Buda Limestone is transitional to disconformable depending on locality (Rose, 1972, p. 27, 43). The Buda Limestone outcrop is distinctly nodular with small, calcite-filled veins, and generally is buff to light gray, porcelaneous limestone (Sellards and others, 1933, p. 397). The Eagle Ford Group unconformably overlies the Buda Limestone (Arnow, 1959). The Eagle Ford Group consists of thin flagstones of brown, flaggy shale and argillaceous limestone. Some of the freshly fractured flagstones emit a petroliferous odor, indicative of a high organic content.

Field identification of the various members in the Kainer and Person Formations was based on their characteristic lithologies and fossils (table 1). Red clay soil that resembles the "terra rossa" of Pleistocene age, described by Young (1986, p. 63) as a diagenetically altered paleosol, commonly is evident in outcrops of the Edwards Group, but rarely in the Glen Rose Limestone or in the clays or limestones of the upper confining units. According to Young (1986, p. 65), the red clay soil indicates that lithology was important in the development of central Texas terra rossa. Large accumulations of terra rosa relative to the volume of pore space in the limestone decrease the effective porosity and, thereby, decrease the permeability.

\section{HYDROGEOLOGIC CHARACTERISTICS}

\section{General Features}

The Edwards aquifer has relatively large permeability resulting, in part, from the development or redistribution of secondary porosity (Maclay and Small, 1976). Lithology, stratigraphy, diagenesis, and selective dissolution (karstification) account for the effec- tive porosity and permeability in the Edwards aquifer outcrop. Karst features that can greatly enhance the effective porosity in the outcrop include sinkholes and caves. The dry-subhumid climate (Thornthwaite, 1952) is not favorable for rapid karst development. The presence of caves in the Edwards Group limestone in Bexar County is random and the morphology is controlled by the local stratigraphy.

\section{Porosity and Permeability}

According to Choquette and Pray (1970, p. 212), porosity in sedimentary carbonates is either fabric selective or not fabric selective. Fabric-selective porosity is secondary porosity that preferentially developed along specific sedimentary structures, strata, or mineralogy. Not-fabric-selective porosity is secondary porosity that developed generally without influence of sedimentary structures as well as secondary porosity that developed preferentially along fractures or faults not associated with the original sedimentary or diagenetic processes. Effective, or drainable, porosity consists of pores that are well-connected by sufficiently large openings, generally greater than 0.1 micrometer in diameter. In the Edwards aquifer, effective porosity is more closely associated with large permeability than with total porosity, which includes unconnected or dead-end pores (Maclay and Small, 1976).

Permeability is the capacity of a porous rock to transmit water. According to Ford and Williams (1989, p. 130), permeability depends on the physical properties of the rock, particularly pore size, shape, and distribution. Ford and Williams (1989, p. 150) further state that, "As a consequence of the effects of fissuring and differential solution, permeability may be greater in some directions than in others as well as in certain preferred stratigraphic horizons."

Downdip from the recharge zone, the Edwards aquifer is confined above and below (table 1). The lower and upper confining units, the eight hydrogeologic subdivisions and the names of the corresponding members, and the type of porosity and permeability observed in the field within the subdivisions are discussed in ascending order.

The upper member of the Glen Rose Limestone is relatively impermeable and generally acts as a lower confining unit of the Edwards aquifer. However, in some areas, the upper member of the Glen Rose Limestone yields substantial quantities of water to wells. 
Hydrogeologic subdivision VIII (basal nodular member) has negligible porosity and permeability in the subsurface, and can be regarded as part of the lower confining unit (Maclay and Small, 1984). In the outcrop, this subdivision is extensively karstified and has secondary porosity in the form of large lateral caves. The lateral cave development might result from dissolution associated with perching of infiltrating meteoric water on the underlying relatively impermeable upper member of the Glen Rose Limestone (Kastning, 1986). The perching would allow time for dissolution to occur within this subdivision. Many seeps and springs discharge from the lower part of this hydrogeologic subdivision in Bexar County.

Hydrogeologic subdivision VII (dolomitic member) generally is porous and relatively permeable. Some of the evaporite beds within this subdivision are burrowed and dissolved to the extent of being honeycombed and, therefore, permeable. Many of the beds contain isolated molds, casts, and burrows with large secondary (fabric selective) porosity but little permeability because the openings rarely are connected. Therefore, the permeable layers are restricted to solution-enlarged bedding planes.

Hydrogeologic subdivision VI (Kirschberg evaporite member) appears to be the most porous and permeable subdivision of the Kainer Formation. The porosity, chiefly fabric selective, has been described as boxwork (Maclay and Small, 1976) because of the configuration of voids and the secondary neospar and travertine deposits. The boxwork porosity does not prevail throughout hydrogeologic subdivision VI, but is interbedded with massive limestone beds.

Hydrogeologic subdivision V (grainstone member) is widely recrystallized. The recrystallization greatly reduces the effective porosity and permeability of this subdivision; however, there is local interparticle and intraparticle porosity and local fracture porosity and permeability.

Hydrogeologic subdivision IV (regional dense member) is probably an effective vertical confining unit between the underlying Kainer Formation and the overlying members of the Person Formation. However, caves, faults, and fractures, primarily not-fabricselective porosity, and fracture-associated permeability, might greatly reduce the confining effects of this subdivision in some areas. Many of the caves in this subdivision are vertical shafts with major horizontal cavern development either above or below the subdivision.
Hydrogeologic subdivision III (leached and collapsed members, undivided) is the most porous and permeable subdivision within the Person Formation. The predominant type of porosity in this subdivision is not fabric selective where evaporite minerals have been dissolved. However, breccia porosity resulting from evaporite dissolution can be either fabric selective or not fabric selective (Choquette and Pray, 1970). Cave porosity and permeability associated with faulting and (or) evaporite dissolution also is common.

Hydrogeologic subdivision II (cyclic and marine members, undivided) is moderately permeable, with both fabric- and not-fabric-selective porosity. Field observations indicate that this subdivision has only slightly less porosity and permeability than subdivision III.

Hydrogeologic subdivision I (Georgetown Formation) yields little water to wells. This subdivision has negligible porosity and permeability. Where severely weathered in the outcrop (and, thus, relatively more permeable), this subdivision is considered a part of the unsaturated zone of the Edwards aquifer.

The upper confining units consist of the Del Rio Clay, Buda Limestone, and the Eagle Ford Group (Rose, 1972). Because the Del Rio Clay consists mostly of clay and has negligible effective porosity and permeability, it forms the primary upper confining unit of the Edwards aquifer.

\section{SUMMARY}

The Edwards aquifer is one of the most productive carbonate aquifers in the nation. It is the sole source of public-water supply for San Antonio and for most of Bexar County. In addition, the Edwards aquifer provides large quantities of water to agriculture, industry, and major springs. The major springs support recreational activities and businesses, provide water to downstream users, and provide habitat for several threatened or endangered species.

The dissolution-modified, faulted limestone aquifer is recharged in its outcrop area in the Balcones fault zone. In Bexar County, residential and commercial development on the recharge zone of the Edwards aquifer is increasing. The aquifer possibly can be contaminated by spills, leakage of hazardous materials, or runoff from the rapidly developing urban areas that surround, or are built on, the intensely faulted and fractured, karstic limestone outcrop of the recharge zone. Furthermore, some of the hydrogeologic subdivisions 
that compose the Edwards aquifer have greater effective porosity than others, and might provide more efficient avenues for contaminants to enter the aquifer in areas where they crop out.

The Edwards aquifer comprises the Kainer and Person Formations of the Edwards Group and the overlying Georgetown Formation. The Kainer and Person Formations consist of seven informal members. These seven members, together with the overlying Georgetown Formation, compose the eight informal hydrogeologic subdivisions of the aquifer.

The Edwards aquifer has relatively large permeability resulting, in part, from the development or redistribution of secondary porosity. Lithology, stratigraphy, diagenesis, and karstification account for the effective porosity and permeability in the Edwards aquifer outcrop. Karst features that greatly enhance effective porosity and permeability include sinkholes and caves.

Hydrogeologic subdivision VI (Kirschberg evaporite member) appears to be the most porous and permeable subdivision in the Kainer Formation. Hydrogeologic subdivision III (leached and collapsed members, undivided) is the most permeable subdivision in the Person Formation. Hydrogeologic subdivision II (cyclic and marine members, undivided) is moderately porous and permeable.

\section{REFERENCES CITED}

Arnow, Ted, 1959, Ground-water geology of Bexar County, Texas: Texas Board of Water Engineers Bulletin 5911, $62 \mathrm{p}$.

Bader, R.W., Walthour, S.D., and Waugh, J.R., 1993, Edwards aquifer hydrogeologic status report for 1992: Edwards Underground Water District Report 93-05, $71 \mathrm{p}$.

Buszka, P.M., 1987, Relation of water chemistry of the Edwards aquifer to hydrogeology and land use, San Antonio region, Texas: U.S. Geological Survey WaterResources Investigations Report 87-4116, 100 p.

Buszka, P.M., Zaugg, S.D., and Werner, M.G., 1990, Determination of trace concentrations of volatile organic compounds in ground water using closed-loop stripping, Edwards aquifer, Texas: Bulletin of Environmental Contamination and Toxicology, p. 507-515.

Choquette, P.W., and Pray, L.C., 1970, Geologic nomenclature and classification of porosity in sedimentary carbonates: American Association of Petroleum Geologists Bulletin, v. 54, no. 2, p. 207-250.

Dunham, R.J., 1962, Classification of carbonate rocks according to depositional texture, in Classification of
Carbonate Rocks Symposium: American Association of Petroleum Geologists Memoir 1, p. 108-121.

Ford, D.C., and Williams, P.W., 1989, Karst geomorphology and hydrology: London, Chapman and Hall, $601 \mathrm{p}$.

Kastning, E.H., 1986, Cavern development in the New Braunfels area, central Texas, in Abbott, P.L., and Woodruff, C.M., Jr., eds., The Balcones escarpmentgeology, hydrology, ecology and social development in central Texas: Geological Society of America, p. 91100.

Kipp, G.K., Farrington, P.T., Albach, M.J., 1993, Urban development on the Edwards aquifer recharge zone: Edwards Underground Water District Report 93-09, $40 \mathrm{p}$.

Maclay, R.W., and Small, T.A., 1976, Progress report on geology of the Edwards aquifer, San Antonio area, Texas, and preliminary interpretation of borehole geophysical and laboratory data on carbonate rocks: U.S. Geological Survey Open-File Report 76-627, 65 p.

1984, Carbonate geology and hydrology of the Edwards aquifer in the San Antonio area, Texas: U.S. Geological Survey Open-File Report 83-537, 72 p.

Rose, P.R., 1972, Edwards Group, surface and subsurface, central Texas: Austin, University of Texas, Bureau of Economic Geology Report of Investigations 74, 198 p.

Sellards, E.H., Adkins, W.S., and Plummer, F.B., 1933, The geology of Texas, v. 1, Stratigraphy: Austin, University of Texas, Bureau of Economic Geology Bulletin 3232, $1,007 \mathrm{p}$.

Small, T.A., 1985, Identification and tabulation of geological contacts in the Edwards aquifer, San Antonio area, Texas: Texas Department of Water Resources LP-199, $54 \mathrm{p}$.

Suppe, J., 1985, Principles of structural geology: Englewood Cliffs, N. J., Prentice-Hall, 537 p.

University of Texas, Bureau of Economic Geology, 1974, Geologic atlas of Texas, San Antonio sheet: Scale 1:250,000.

Thornthwaite, C.W., 1952, Evapotranspiration in the hydrologic cycle, in The physical and economic foundation of natural resources, v. II, The physical basis of water supply and its principal uses: U.S. Congress, House of Representatives, Committee on Interior and Insular Affairs, p. 25-35.

Veni, George, 1988, The caves of Bexar County (2d ed.): Austin, University of Texas, Texas Memorial Museum, Speleological Monographs 2, $300 \mathrm{p}$.

Young, Keith, 1986, The Pleistocene terra rossa of central Texas, in Abbott, P.L., and Woodruff, C.M., Jr., eds., The Balcones escarpment-geology, hydrology, ecology and social development in central Texas: Geological Society of America, p. 63-70. 


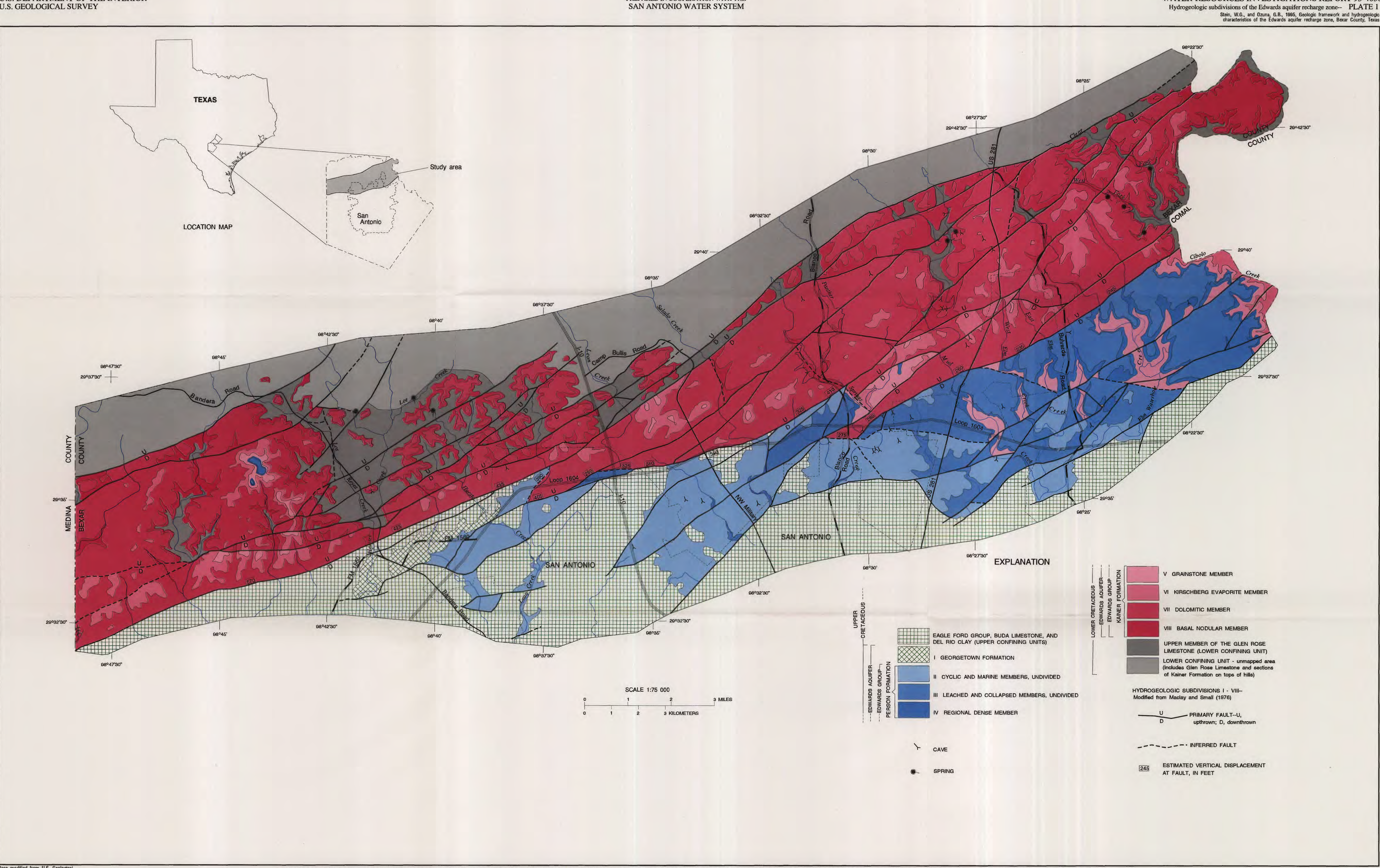

